\title{
Ande-Ande Lumut: Adaptasi Folklor ke Teater Epik Brecht
}

\author{
Philipus Nugroho Hari Wibowo ${ }^{1}$ \\ Jurusan Teater, Fakultas Seni Pertunjukan, Institut Seni Indonesia Yogyakarta
}

\begin{abstract}
ABSTRAK
Karya ini mengadaptasi folklor "Ande-Ande Lumut" sebagai ide dasar penciptaannya. Folklor ini dituangkan dalam pementasan teater berjudul "Kemuning". Folklor "Ande-Ande Lumut" merupakan turunan dari cerita Panji yang menceritakan pengembaraan Raden Panji mencari Putri Candrakirana. Cerita Panji tidak hanya dikenal di Indonesia, tetapi dikenal hingga Asia Tenggara dan Jepang. Perkembangan teori adaptasi begitu pesat, apapun kini bisa dijadikan obyek adaptasi, puisi, novel, drama panggung, lukisan, tarian, dan video games. "Kemuning" ini dikemas dengan konsep pemanggungan teater epik Brecht. Hal ini merupakan suatu upaya mencari bentuk baru (pembacaan) dalam cerita "Ande-Ande Lumut". Teater Epik menolak salah satu unsur utama dari drama Aristoteles yang telah dikembangkan dengan metode Stanislavsky, yaitu harus adanya empati (rasa ikut mengalami) dalam sebuah pementasan. Menurut Brecht proses ini telah menyebabkan suatu akibat yang mestinya dihindari, karena mengakibatkan sikap pasif dalam diri penonton. Maka ia membuat teori tentang menghancurkan ilusi, cara interupsi, dan tetap mengontrol emosi. Brecht identik dengan tema-tema sosial dalam karyanya. khususnya tema yang mengangkat nasib orang kecil yang harus menderita karena kebijakan penguasa. Biasanya kisahnya seputar persoalan buruh dan majikan. Pementasan "Kemuning" ini mengangkat kehidupan para pelacur yang masih identik dengan hal-hal negatif. Padahal mereka dibutuhkan dalam masyarakat. Tapi kadang kala mereka menjadi kambing hitam yang harus selalu disalahkan. Secara tersirat pementasan ini bertujuan memperjuangkan kehidupan para pelacur. Penonton diajak melihat sudut pandang yang lain tentang kehidupan pelacur yang selama ini dianggap buruk oleh masyarakat. Menurut Brecht teater yang baik dan yang dituntut dalam jaman moderen adalah teater yang dapat menggugah aktifitas berfikir yang kritis pada diri penonton. Maka pentas ini diharapkan mendorong para penikmat seni untuk melahirkan penafsiran yang penuh dengan kesadaran terhadap lingkungan sosial dan bisa menimbulkan suatu gerakan atau perubahan pada masyarakat.
\end{abstract}

Kata kunci: Folklor, Ande-Ande Lumut, Adaptasi, dan Teater Epik Brecht

\begin{abstract}
Ande-Ande Lumut: The Adaptation of Folklore to the Epic Theater of Brecht. This theatrical work is adapted from a popular folklore entitled Ande-Ande Lumut that is as a basic idea of its work. This folklore is performed in theatrical performance entitled Kemuning. Ande-Ande Lumut is a story derived from the story of Panji which tells us about Prince Panji's journey to look for Princess Candrakirana. This story is not only popular in Indonesia but also in South East Asia and Japan. The adaptation theory is developing well; everything can be used as an adaptation object, poems, novels, dramas, paintings, dances, and video games. Kemuning is performed by the performing concept of Brecht's epic theater. However, this is an effort to find out the new form of reading in Ande-Ande Lumut story. The epic theater against one of the main elements in Aristotle's drama that has been developed by Stanislavsky's method; there should be an empathy in every aspect of performance. According to Brecht, this process has caused an effect which should be avoided because it brings audience's passive attitude. Therefore, he tried to make a theory of destroying the illusion, of interrupting method, and of controlling emotion. Brecht's identical works focus on the social themes, especially on the themes that show the poor people who are suffering from the authority's policy. The common problems between the master and its worker are reflected on his story. The Kemuning performance has tried to show the prostitutes' life that is closed to any negative things. In fact, they are still being needed by the society. Unfortunately, sometimes they become the source of scapegoats to any troubles and are always blamed to. Implicitly, this performance is aimed to fight for the prostitutes' life. The audience is invited to see the other points of view about their life that are often regarded as negative by the people. Moreover, Brecht said that a good and demanded theater in this modern era is a theater that can arouse the audience's critical thinking activities. Therefore, this performance is supposed to be able to motivate the arts lovers in producing a critical analysis to any social awareness and in creating a new movement to any significant changes in society.
\end{abstract}

Key word: Folklore, Ande-Ande Lumut, Adaptation, and Brecht' Epic Theater

\section{Pendahuluan}

Adaptasi folklor Ande-Ande Lumut menjadi sebuah pementasan teater dengan konsep teater epik Brecht merupakan suatu upaya mencari bentuk baru (pembacaan) dalam cerita Ande-
Ande Lumut. Hal tersebut tidak bisa dipungkiri karena seiring perkembangan zaman, interprestasi dongeng Ande-Ande Lumut akan selalu berubah, bergerak mengikuti jamannya. Pemilihan folklor merupakan suatu upaya mencari ide baru dalam

1 Alamat korespondensi: Jurusan Teater ISI Yogyakarta. Jalan Parangtritis Km 6.5 Sewon, Yogyakarta 55001. Yogyakarta. Telepon (0274) 375380. HP: 08562886994 .E-mail: maliobowo_yk@yahoo.com 
pementasan teater, dengan harapan agar karya ini memberikan stimulan terciptanya pertunjukan teater yang mengambil folklor sebagai ide dasarnya.

Folklor adalah bentuk pengindonesiaan kata dalam bahasa Inggris folklore. Kata tersebut adalah kata majemuk, yang berasal dari 2 kata yakni folk dan lore. Folk dapat diartikan sebagai sekelompok orang yang memiliki ciri-ciri pengenal fisik, sosial, dan kebudayaan, sehingga dapat dibedakan dari kelompok-kelompok lainnya. Sedangkan lore adalah tradisi folk, yakni sebagian kebudayaan yang diwariskan secara turun temurun secara lisan atau melalui sesuatu contoh yang disertai gerakan isyarat atau alat pembantu pengingat (mnemonic device). Jadi folklor adalah sebagian kebudayaan suatu kolektif yang tersebar dan diwariskan turun temurun, di antara kolektif macam apa saja, secara tradisional dalam versi yang berbeda, baik dalam bentuk lisan maupun contoh yang disertai dengan gerak isyarat atau alat pembantu pengingat (mnemonic device) (Danandjaya, 1986: 2). Folklor hanya merupakan sebagian kebudayaan, yang penyebarannya pada umumnya melalui tutur kata atau lisan (Danandjaya, 1986: 5).

Dongeng termasuk folklor, tepatnya folklor lisan (sastra lisan) yaitu folklor yang bentuknya murni lisan. Folklor murni lisan ini terbagi dalam 6 kelompok besar yaitu: prosa rakyat, ungkapan tradisional, pertanyaan tradisional, puisi rakyat, cerita prosa rakyat, nyanyian rakyat. Dongeng termasuk dalam cerita prosa rakyat. (Danandjaya, 1986: 21-22). Berbicara dongeng, menjadikan kita seperti kembali pada romantisme masa kanakkanak. Masa-masa yang penuh dengan imajinasi. Meskipun diceritakan berulang-ulang tapi serasa tidak bosan mendengarnya. Menurut James Danandjaja yang dimaksud dengan dongeng adalah cerita prosa rakyat yang tidak dianggap benar-benar terjadi. Dongeng diceritakan terutama untuk hiburan, walaupun banyak yang melukiskan kebenaran, berisikan pelajaran (moral) atau bahkan sindiran (Danandjaya, 1986: 83).

Dongeng Ande-Ande Lumut merupakan turunan dari cerita Panji, seperti halnya Keong Emas, Golek Kencana, Cinde Laras, Timun Emas, Uthak-Uthak Ugel juga yang lainnya, maka terdapat banyak cerita yang saling berbeda namun saling berhubungan, cerita-cerita dalam berbagai versi ini dimasukkan dalam satu kategori yang disebut "Daur Panji" atau "Siklus Panji". Cerita
Panji tidak hanya dikenal di Indonesia, tetapi lebih luas hingga Asia Tenggara (Thailand, Malaysia, Filipina, Vietnam, Kamboja), bahkan Jepang.

Tokoh Ande-Ande Lumut yang merupakan penjelmaan Raden Panji dan merupakan anak angkat Randa Dhadapan dikisahkan sedang mencari jodoh. Sedangkan Kleting Kuning adalah Putri Candrakirana yang sedang menyamar. Ia diangkat anak oleh Nyai Sambega yang mempunyai empat orang anak, Kleting Merah, Hijau, Biru dan Ungu. Nyai sambega mengijinkan Kleting Kuning untuk ikut melamar Ande-Ande Lumut. Pakaian dan penampilannya sangat buruk dan bau, tidak seperti saudara-saudara tirinya yang berangkat dengan pakaian yang bagus, wangi dan dandanan yang cantik. Pada akhir cerita, Ande-Ande Lumut justru memilih Kleting Kuning sebagai istri. Ia tidak peduli meskipun penampilannya buruk dan aromanya tidak sedap. Ande-Ande Lumut tahu Kleting Kuning tidak dicium oleh Yuyu Kangkang, seekor ketam raksasa yang tinggal di sungai. Yuyu Kangkang selalu meminta upah kepada siapa saja yang disebrangkannya, termasuk kepada suadara tiri Kleting Kuning. Upahnya adalah ciuman. Yuyu Kangkang tidak mau menyeberangkan Kleting Kuning karena bau. Kleting Kuning marah. Ia kemudian menghentakkan sapu lidi sakti (sodho lanang) pemberian Bangau Tongtong (seekor burung bangau yang merupakan penjelmaan Dewa) ke sungai. Seketika air sungai menjadi kering. Kleting Kuning kemudian bisa menyebrangi sungai. Setelah dimandikan, akhirnya terbongkarlah penyamaran Putri Candrakirana. Pada akhir ceritera Raden Panji dipertemukan kembali dengan Putri Candrakirana. Keduanya kemudian hidup bahagia.

Dongeng Ande-Ande Lumut memiliki banyak versi, selain disebarkannya melalui bahasa tutur/ lisan, dongeng Ande-Ande Lumut ini bukan saja beredar di Jawa Timur saja melainkan juga di Jawa Tengah (Soedarsono, 1986: 462). Dongeng Ande-Ande Lumut yang awalnya diwariskan secara lisan, kini sudah banyak didokumentasikan, baik lewat tulisan, (buku bacaan anak-anak), audio/ rekaman kaset (dibuat oleh sanggar Prativi), audiovisual (Film/Sinetron), komik, bahkan karena kepopulerannya tersebut, Waljinah membuatkan lagu yang mengkisahkan tentang cerita Ande-Ande Lumut. Dongeng Ande-Ande Lumut juga sudah banyak dipentaskan dalam 
pemanggungan teater, baik modern maupun tradisional. Meskipun demikian, tidak dipungkiri masih banyak juga masyarakat yang melestarikan dongeng Ande-Ande Lumut dengan budaya tutur/ budaya lisan/sastra lisan.

Bunanta (1998: 100) menjelaskan bahwa ia menemukan 12 versi Ande-Ande Lumut sampai kurun waktu penelitiannya, pada tahun 1998 di antaranya tidak dituliskan khusus sebagai bacaan anak-anak, yaitu versi Luinenburg (1904), versi Bratasoesastra (1922), Dongeng versi Le'Olle' (1941), versi Van der Horst-van Doorn (1929), versi Hadisutjipto (1975), versi Soemiati Soetjipto (1975), versi Dananjaya (1976), versi Arti Purbani (1976), versi Aske Ba (1978), versi K. Usman (1985), versi Nora Hasyati (1990), versi Notosiswoyo (1991). Selama proses penelitian penulis menemukan empat versi lagi, Versi Tira Ikranegara, Versi M. Syafii Maskur (2011), versi Surasdi (1986), Versi Soeratinah, dan jika ditambah versi penulis, Versi Philipus Nugroho Hari Wibowo (penulis) ditulis pada tahun 2012. Meskipun ada berbagai versi, tetapi pola cerita mempunyai satu pola baku, yaitu perpisahan dan pertemuan kembali Ande-Ande Lumut dan Kleting Kuning, hal tersebut karena cerita ini berasal dari cerita Panji dan bersifat Migratoris (Dananjaya, 1984: 67), yaitu cerita dapat berpindah-pindah sehingga dikenal luas di daerah yang berbeda.

Dalam buku The Types Of The Folkore, Aarne dan Thompson membagi dongeng menjadi 4 golongan, dongeng binatang, dongeng biasa, lelucon dan anekdot, dan dongeng berumus (Aarne, 1964: 19-20). Dongeng Ande-Ande Lumut termasuk dalam kategori dongeng biasa. Dongeng biasa adalah dongeng yang ditokohi oleh manusia dan biasanya adalah kisah duka seseorang. Di Indonesia dongeng biasa yang paling populer adalah yang bertipe Cinderela dan bermotif unpromising heroin (tokoh wanita yang tak ada harapan dalam hidupnya). Dongeng biasa yang bertipe Cinderela ini bersifat universal karena tersebar hampir di seluruh belahan dunia.

\section{Adaptasi Bebas}

Adaptasi merupakan sebuah langkah yang bisa dikatakan mudah, tetapi bisa juga sebaliknya. Hal ini disebabkan karena proses adaptasi haruslah memiliki nilai yang lebih dari sumber- sumbernya. Upaya adaptasi dari satu bentuk naskah menjadi bentuk lain (naskah), sudah terjadi dan terus berlangsung. Linda Hutcheon mengatakan dalam bukunya yang berjudul Theory Of Adaptation, suatu kesalahan yang besar jika kita berfikir bahwa adaptasi hanya dapat dilakukan pada novel dan film, apapun bisa kita adaptasi, puisi, novel, drama panggung, lukisan, tarian, bahkan video games, apapun bisa kita jadikan obyek untuk diadaptasi (Hutcheon, 2006: 11). Rihcard Krevolin mengatakan bahwa adaptasi adalah proses menangkap esensi sebuah karya asli untuk dituangkan kedalam media lain. Memang tidak bisa dihindari, beberapa elemen akan tetap digunakan dan beberapa lainnya akan ditinggalkan, tapi jiwa cerita itu haruslah tetap sama (Krevolin 2003: 78). Pada proses adaptasi terjadi proses intertekstualitas.

Menurut Julia Kristeva dalam Joko Pradopo (1984: 167), bahwa setiap teks sastra itu merupakan mozaik kutipan-kutipan, penyerapan dan transformasi dari teks lain, maka tak ada karya yang mencontoh atau meniru karya sebelumnya. Teks dalam pengertian umum adalah dunia semesta ini, bukan hanya teks tertulis ataupun teks lisan. Adat istiadat, Kebudayaan, film, drama secara pengertian umum adalah teks. Oleh karena itu karya sastra tidak boleh lepas dari hal-hal yang menjadi latar penciptaan tersebut, baik secara umum maupun secara khusus. Untuk dapat menemukan dan menafsirkan respons itu adalah merupakan tugas pembaca (Teeuw, 1983: 65)

Julia Kristeva dalam A. Teeuw (1988: 145) menjelaskan, setiap teks sastra dibaca dan harus dibaca dengan latar belakang teks-teks lain. Menurutnya takada sebuah teks pun yang sungguhsunguuh mandiri, dalam arti bahwa penciptaan dan pembacaannya tidak dapat dilakukan tanpa adanya teks-teks lain. Berpijak dari hal tersebut, maka apabila ada gejala keterpengaruhan pada teks-teks sebelumnya yang sudah dibaca pada karya yang akan diciptakan menjadi sangat logis. Dalam perkembangan teater modern (masa kini) Indonesia ada beberapa karya teks yang memperlihatkan gejala keterpengaruhan dari naskah sebelumnya. Puti Bungsu karya Wisran Hadi merupakan kontra mitos (pertentangan) dari lakon sebelumnya yang telah ada di Indonesia, yaitu Malin Duano, Malin Kundang, Tangkuban perahu (Yuliady, 1995: 3) 
Karya Sastra tidak lahir dalam situasi yang kosong, tidak lepas dari sejarah sastra. Artinya, sebelum karya sastra dicipta, sudah ada karya sastra yang mendahuluinya. Pengarang tidak begitu saja mencipta, melainkan ia menerapkan konvesikonvensi yang sudah ada. Disamping itu, ia juga berusaha menentang atau menyimpangi konvensi yang sudah ada. Karya sastra selalu ada dalam ketegangan antara konvensi dan revolusi, antara yang lama dan yang baru (Teeuw, 1980: 12). Oleh karena itu untuk memberi makna karya sastra, maka prinsip kesejarahan itu harus diperhatikan. Sebuah karya sastra baru mempunyai makna penuh dalam hubungan atau pertentangan nya dengan karya sastra lain. Ini merupakan prinsip intertektualitas yang ditekankan oleh Riffaterre (Teeuw, 1983: 65). Sering kali sebuah karya berdasar atau berlatar pada karya sastra yang lain, baik karena menentang atau meneruskan karya sastra yang menjadi latar itu. Menurut Riffaterre melalui Joko Pradopo (1995:112), karya sastra yang menjadi dasar atau latar penciptaan karya sastra disebut hypogram. Sebuah karya sastra akan dapat diberi makna secara hakiki dalam konteks nya dengan hypogram nya (Teeuw, 1983: 66). Selanjutnya, gejala keterpengaruhan pada gaya ungkap atau struktur penulisan dalam lakon, merupakan perkembangan dalam penulisan. Teks yang menyerap dan mentransformasikan hypogram itu disebut sebagai teks transformasi (Pradopo, 1995: 132). Maka dengan merujuk pada intertekstualitas akan ditemukan hypogram guna melandasi karya-karya baru dari Dongeng Ande-Ande Lumut.

Dongeng Ande-Ande Lumut diadaptasi secara bebas dengan kehidupan pelacuran. Kehidupan pelacur dan pelacuran masih identik dengan hal- hal negatif. Terkadang mereka menjadi kambing hitam yang harus selalu disalahkan. Melalui pementasan teater berjudul Kemuning yang mengangkat kehidupan para pelacur di pelacuran ini, diharapkan secara langsung atau tidak langsung membuat masyarakat tahu betul kondisi dan problematika pelacur. Diharapkan masyarakat mempunyai pandangan yang lain dalam melihat kehidupan para pelacur.

\section{Teater Epik Brecht}

Tema dongeng Ande-Ande Lumut ini sangat relevan dengan konsep teater epik Brecht. Kleting
Kuning disimbolkan sebagai buruh yang menuntut haknya, ia dieksploitasi oleh saudara tirinya yang disimbolkan sebagai majikan. Teater epik Brecht selalu mengangkat tema yang serupa yaitu nasib orang kecil yang harus menderita karena kebijaksanaan penguasa, menampilkan persoalan buruh dan majikan. Tema sosial seperti inilah yang mencirikan teater epik Brecht. Satu hal yang sangat esensial, teater epik Brecht bertujuan menggugah aktivitas berfikir pada manusia, harapannya bisa menimbulkan suatu gerakan atau perubahan. (Nugroho, 2011: 14)

Dalam bukunya yang berjudul Ikhtisiar Teater Barat, Jakob Soemardjo menjelaskan, Epik secara sengaja dipakai untuk menamai teater Brecht sebab teaternya lebih mirip cerita-cerita epos dari teater tradisional. Pada cerita epos jalinan puisi dan prosa silih berganti secara bebas, seluruh cerita dilihat oleh si pencerita bahkan pembatasan waktu dilakukan secara amat bebas. Si pencerita dapat meloncat dari satu waktu ke waktu jauh sesudahnya hanya dalam satu ucapan saja. Pada praktek pementasannya, teater epik memang sangat bebas menjelajahi waktu dan tempat, dalam pentas yang itu-itu juga. Inilah sebabnya pengaruh slide projector dan karikatur raksasa adalah wajarwajar saja dalam teater mereka. (Sumardjo,1986: 99-100).

Pendapat Jakob Soemardjo tersebut menggambarkan bagaimana Brecht melakukan inovasi dalam teknik pemanggungan sebuah naskah. Dengan teknik tersebut sebuah naskah dan pementasan di tangan Brecht akan menjadi sangat dinamis. Secara estetis ia akan lebih menarik untuk dillihat, oleh karena itulah penggabungan dengan multimedia yang berupa film menjadi sangat relevan dalam penggarapan nantinya. Secara visual film akan lebih menarik dari pada pertunjukan teater jika disuguhkan pada satu pemanggungan bersama-sama. Hal ini dikarenakan film merupakan cahaya. Adegan satu dengan adegan yang lain bisa menjadi terputus, tetapi dengan konsep teater epik Brecht pemutusan adegan ini tidak menjadi sebuah permasalahan.

Ephishes theatre atau teater epik menolak salah satu unsur utama dari drama Aristoteles yang telah dikembangkan dengan metode Stanislavsky, yaitu harus adanya empati (rasa ikut mengalami) dalam sebuah pementasan. Menurut Brecht proses ini telah menyebabkan suatu akibat yang sebenarnya 
mestinya dihindari, karena mengakibatkan sikap pasif dalam diri penonton. Lakuan dramatis yang memukau di atas panggung mengakibatkan penonton terlibat secara emosional. Kondisi semacam ini membuat penonton terombangambing, hanyut, oleh pikiran dan perasaan pemain yang pada saat itu juga sebenarnya sedang mengidentifiasikan dirinya dengan figur yang diperankannya. Menurut Brecht dalam Koes Yuliadi (1995: 9-10), hal semacam ini ini tidak mendidik dan tidak sesuai dengan nafas jaman baru. Teater yang baik dan yang dituntut dalam jaman moderen adalah teater yang dapat menggugah aktifitas berfikir yang kritis pada diri penonton. Brecht dalam Greg Soetomo (2002: 103) menegaskan bahwa karya seni progesif haruslah menghasilkan sesuatu yang bersifat reflektif, bukan hanya tanggapan emosional, dengan begitu hal ini akan mendorong para penikmat seni untuk melahirkan penafsiran yang penuh dengan kesadaran terhadap lingkungan sosial.

Seperti halnya pemahaman marxis yang percaya bahwa nilai sangat ditentukan oleh kekuatan sistem ekonomi, makadalamsetiappertunjukannya Brecht yang juga telah mendalami marxis berusaha membuat penonton mengevaluasi implikasi sosial ekonomi terhadap diri mereka setelah menyaksikan apa yang ditampilkan dalam teater. Brecht dalam Yudiaryani (2002: 249-250) percaya jika ini berlangsung secara efektif, penonton akan percaya pada kebutuhan untuk mengubah kondisi sosial, serta berupaya melakukan perubahan yang sesuai bagi diri mereka sendiri. Selanjutnya Brecht mengatakan bahwa teaternya tidak memberikan jawaban terhadap persoalan masyarakat, namun ia mendukung sikap aktif dan kritis yang dimiliki penonton terhadap panggung.

Brecht tidak memiliki latihan pemeranan khusus seperti Stanislavsky yang mempunyai metode pelatihan bagi aktor. Para pemain dalam teater Brecht menghindari akting yang hendak mempertontonkan akting secara penuh dengan perannya. Maka ia bermain dan mempertontonkan sesuatu, daripada mengambil tingkah laku karakternya sendiri. Pemain tidak diperbolehkan mengizinkan dirinya untuk berubah menjadi karakter yang ia inginkan di atas pentas. Ia bukan Lear, Harpagon, dalam arti sesungguhnya. Ia hanya mempertontonkan siapa mereka itu. Maka perannya adalah menghadirkan kembali karakter mereka se-autentik mungkin, dengan begitu ia tidak boleh mengubah karakter mereka sekehendak sang pemain (Soetomo, 2002: 111). Dengan menolak empati maka penonton tidak diperbolehkan terbawa dengan kejadian di atas pentas. Pentas adalah tontonan yang harus dihadapi dengan kritis. Dengan begitu penonton tidak hanya melihat teater sebagai hiburan, tetapi juga bisa berpartisispasi di dalamnya. Brecht dalam Soetomo (2002: 108) menyakini bahwa penonton adalah sekumpulan individu-individu yang mampu berfikir dan berargumentasi, serta membuat penilaian terhadap apa yang berlangsung di atas panggung itu sendiri. Dengan demikian, Brecht menolak segala konsep mengenai proses pencerahan sebagaimana yang dipikirkan oleh teater klasik.

Dengan teater epiknya, Brecht ingin membangun penontonnya, membuat mereka berfikir, membandingkan, mempertanyakan, dan melihat dampak naskah drama bagi kehidupan mereka sendiri, tidak sekedar menenggelamkan diri mereka kedalam persoalan psikologis kalangan orang berada, maka ia membuat teori tentang menghancurkan ilusi, cara interupsi, tetap mengontrol emosi. Istilah kesukaan nya adalah Verfremudungs Effekt yang selalu diterjemahkan dengan alinasi atau "Efek- $A$ ", istilah bahasa Inggris yang tepat adalah objektivitas (Yudiaryani, 2008: 122-123). Alinasi sebenarnya bukanlah kata yang tepat untuk menerjemahkan Verfremudungs Effekt (V-effekt) ke dalam bahasa Inggris. Menurut Brecht V-effekt adalah usaha untuk menggambarkan sebuah peristiwa kedalam bentuk baru yang bertujuan untuk mencegah penonton menjadi katarsis (Encyclopedia of World Drama, 1972: 250). Brecht benar-benar ingin memutus seluruh jenis ilusi, ia meyakini bahwa teater menjadi lebih baik tanpa ilusi. Brecht tidak menyukai pendekatan akting dengan naturalistik atau Stanislavsky, dimana seorang aktor kehilangan identifikasi pribadinya dihadapan tokoh (Yudiaryani, 2002: 123). Kernodle dalam Yudiaryani (2002: 122), mengatakan teori Brecht dikembangkan melalui bentuk negatif yang merupakan suatu perlawanan terhadap panggung realistik yang telah mapan.

Teater epik dalam berbagai pengertian merupakan bentuk yang memiliki karakteristik dan efektivitas di abad ke-20. Teater ini meminjam beberapa bentuk terbaik dari teater masa lampau- 
primitif, Timur, Yunani dan Elizabethan. Teater ini juga menyerap beberapa sifat seni modern dan seni lainnya seperti ekspresionisme, abstrak, surealisme dan simbolisme. Epik mampu mengolah sejarah dan fantasi (Sumardjo, 1986: 134). Lebih lanjut Jakob Sumarjo menjelaskan bahwa dalam kondisi yang terbaik, teater epik berhasil menjadi alat propaganda yang fleksibel atau untuk mendemonstrasikan fakta dan gagasan yang beragam di atas panggung. Teater ini merupakan pengalaman teatrikal yang menggetarkan dan sangat kaya, melacak perkembangan teater bisa terkait dengan berbagai peristiwa, subjektif dan objektif. Teater ini merupakan salah satu pendekatan tengah abad yang kita sebut dengan teater total sebuah teater yang menggambarkan semua yang dibutuhkan mata, telinga, pikiran dan batin (Sumardjo, 1986: 134). Konsep Teater Epik Brecht ini kemudian membawa pengaruh besar terhadap perkembangan teater dunia.

\section{Pemanggungan}

Pemanggungan dalam drama Brecht merupakan unsur yang sangat penting dalam menunjang keberhasilan V-Effekt. Diperlukan suatu perencanaan dan penerapan yang khusus dalam tata pemanggungan agar penonton bisa selalu menyadari bahwa apa yang disampaikan adalah permainan. Pada naskah-naskah Brecht biasanya sudah diberikan petunjuk-petunjuk yang sangat jelas. Dalam Puntila misalnya, Brecht menyarankan penggunaan tirai sutra yang tipis. Pada saat pergantian adegan, tirai tersebut disorot lampu sehingga akan nampak segala kegiatan yang ada dibalik tirai dalam mempersiapkan adegan selanjutnya. Corak pemanggungan seperti ini tentunya akan menarik bagi penonton. Hal tersebut juga akan mengingatkan penonton kalau itu hanyalah permaianan. Selain itu Brecht juga sering menggunakan informasi lewat tulisan diatas panggung. Dalam Puntila judul-judul adegan diproyeksikan pada tirai, serangkaian jalan cerita bahkan telah tercakup dalam judul tersebut.

Pada pemanggungan Kemuning, adegan yang menggunakan set rumah Bordil "Kembang Sore" bagian dalam (ruang tengah dan kamarkamar) digunakan kayu di bagian bawah sebagai pembatas yang merupakan simbol pintu dan dinding. Ruangan satu dengan ruangan yang lain hanya dibatasi dengan dinding imajiner. Untuk menghadirkan sebuah kamar atau ruang tengah, hanya dihadirkan beberapa benda saja yang secara simbol sudah mencirikan tempat tersebut. Informasi lewat tulisan yang berupa "Roemah Boerdil Kembang Sore" juga dihadirkan diatas panggung, sebagai simbolis keberadaan atau tempat tersebut.

Dalam mewujudkan karya seni ini dipilih konsep pemanggungan dengan menggunakan konsep panggung teater prosenium. Setting pada pemanggungan Kemuning terdiri dari tiga bagian. Pada sisi kiri, merupakan teras rumah bordil Kembang Sore, sedang di bagian tengah merupakan ruang tengah dan kamar-kamar Kembang Sore, pada adegan babak 8 dan 11 sebagian ruangan (kamar) akan dilapisi dengan plastik buble pack, dan akan ditembakkan dengan lampu, sehingga kesan siluet akan muncul. Dari atas panggung yang sudah diperhitungkan sudutnya Adegan tersebut direkam dengan kamera dengan menggunakan konsep long take, dan divisualisasikan pada layar yang sudah disiapkan di bagian depan. Maka secara visual ada dua sudut pandang penonton. Dengan media plastik buble pack akan terlihat siluet, sedang dengan media kamera akan terlihat lebih realis, meskipun realisme film, panggung dan kehidupan nyata berbeda. Pada bagian kiri panggung merupakan setting jalan. Perpindahan tempat dan waktu dibarengi oleh pertukaran setting decoration. Dengan cepat setting (tempat dan waktu) yang ada diatas panggung bisa berubah mengikuti tuntutan cerita (mobile). Hal tersebut dapat dilakukan juga dengan pengaturan lampu yang berpindahpindah sehingga tinggal mematikan lampu (black out) dan kemudian dinyalakan lagi. Sebuah setting baru telah tercipta. Bahkan dengan dialog seorang tokoh pun, setting baru bisa dihadirkan.

Setting waktu pada pementasan ini dibuat seperti tahun 70-an. Meskipun gaya berbicara dan gaya berpakaian merujuk pada tahun tersebut, tetapi isu ceritanya berbicara tentang masa kini. Terutama tentang krisis kepemimpinan. Hal ini termasuk usaha dalam kontek "Pengasingan" yang dilakukan dalam konsep teater epik Brecht. Pada saat ini, kondisi masyarakat sedang mengalami krisis kepemimpinan, masyarakat sudah tidak percaya lagi terhadap pemimpin, sehingga perlu adanya sosok pemimpin yang baru. Para pemimpin dan birokrat cenderung 
untuk mencari keuntungan diri mereka sendiri dengan melakukan korupsi. Pekerjaan pelacur seakan lebih mulia dari pada para koruptor. Pada pementasan ini ada sebuah penawaran baru, bahwa lelaki dan wanita sudah tidak layak lagi untuk memimpin negara. Mungkin alternatif baru adalah penggabungan antara keduanya, Waria alias wanita-pria. Pada beberapa adegan terdapat tarian (koreografi) dan nyanyian, tapi hal ini bukan mengindikasikan bahwa pertunjukan ini merupakan drama musikal. Hal ini sematamata dibuat untuk semakin memperkuat konsep teater epik, yaitu untuk menyadarkan penonton dari empati.

\section{Pemeranan}

Tokoh dalam Teater Epic Brecht selain bertujuan untuk membawa pesan yang ingin disampaikan pengarang, juga memberikan kesadaran pada penonton, bahwa apa yang dilihat di atas panggung adalah suatu tontonan yang harus dinilai dan dipahami. Seperti halnya tujuan teater epik Brecht sendiri, selain empati penonton, konsep teater epik Brecht juga menghindari empati para tokohnya. Hal ini pulalah yang membuat pemeranan teater epic Brecht berbeda dengan drama klasik. Brecht tidak menyukai pendekatan akting dengan naturalistik atau Stanislavsky, di mana seorang aktor kehilangan identifikasi pribadinya di hadapan tokoh, menurut Brecht pemain harus melepaskan empati mereka dengan tokoh dan lakuan yang ia mainkan.

Pemain tidak diperbolehkan mengizinkan dirinya untuk berubah menjadi karakter yang ia inginkan di atas pentas. Pemain bukan tokohtokoh yang mereka mainkan di atas pentas, mereka hanya mempertontonkan siapa mereka itu. Peran para pemain adalah menghadirkan kembali karakter mereka seautentik mungkin, dengan begitu ia tidak boleh mengubah karakter mereka sekehendak sang pemain. Dalam hal ini pemain dapat berpindah dengan begitu cepatnya dari peran tokoh, kemudian menjadi dirinya sendiri. Pemain pada pementasan Kemuning ini betul-betul sadar bahwa mereka sedang berakting. Mereka begitu cepatnya keluar dari peran, kemudian masuk lagi menjadi dirnya sendiri, orang lain, kemudian kembali lagi menjadi peran mereka kembali. Beberapa pemain melakukan akting yang kesannya dilebih-lebihkan. Hal ini juga merupakan salah satu cara mencapai alinasi. Dengan kehadiran setting yang hanya dibatasi dengan kayu, imajinasi pemain (para pelacur) sengaja dibangun dan menyepakati bahwa dinding imajiner itu terbentuk. Hal inilah yang kemudian menyadarkan pemain bahwa mereka betul-betul sedang berperan, meskipun di depan mata mereka melihat adegan di ruangan yang lainnya. Pencapaian alinasi yang lain dapat dilihat ketika aktor bernyanyi pada saat mengalami kesedihan. Meskipun para pemain melakukan alinasi, pencapaian alinasi pada aktor tersebut tetap dikemas, dan tidak asal-asalan, karena butuh waktu yang tepat untuk melakukan alinasi.

Dalam lakon ini terdapat tokoh Dalang yang sekaligus merupakan tokoh Centeng. Tokoh dalang bertugas sebagai pencerita dan menjalin satu adegan dengan adegan yang lain. Sebelum atau sesudah adegan berlangsung ada semacam ringkasan cerita yang disampaikan oleh Dalang, begitu juga pada bagian prolog dan epilog. Hal ini berguna supaya penonton memahami cerita, dan tidak terhanyut dalam cerita (empati), kesadaran penonton akan cerita membuat mereka terhindar dari empati. Semua hal tersebut di atas pada intinya bermuara pada konsep pemanggungan yang mengacu pada konsep pemanggungan teater epik Brecht.

\section{Tata Cahaya}

Tata cahaya mempunyai peranan yang penting dalam pementasan Kemuning. Seperti sudah dijelaskan sebelumnya, proses pergantian adegan dalam pementasan ini banyak menggunakan lampu. Dengan perpindahan lampu, adegan dan setting baru sudah terwujud. Selain itu dengan adanya tata cahaya, pertunjukan akan menjadi lebih hidup. Fokus karakter atau tokoh dapat dimunculkan dengan cahaya. Demikian pula keseimbangan, dapat diciptakan melalui intensitas cahaya. Bahkan perubahan warna setting dekor dan tata panggung dapat diubah sesuai dengan mood cerita melalui cahaya. Cahaya membuat semuanya tampak hidup.

Fungsi tata cahaya secara umum dalam Kemuning adalah untuk membentuk situasi, menyinari gerak pelaku, perpindahan adegan dan mempertajam ekspresi demi penciptaan karakter pelaku juga sebagai media pendukung alinasi. Dengan demikian, imajinasi penonton pada situasi tertentu yang diciptakan dalam pemanggungan dapat tercapai. 


\section{Busana dan Kostum}

Kemuning, Pencari Cinta dan tokoh lainnya mengunakan busana tahun 70-an. Busana lakilaki tahun 70-an identik dengan Kemeja berlengan panjang dan memiliki kerah besar dan panjangyang menjuntai di bagian dada, sedangkan celananya semakin kebawah bentuknya semakin membesar (cutbrai), rambut panjang, gondrong dan mengembang kebagian depan (bukan memanjang kebelakang), topi yang digunakan adalah topi pet. Sepatu yang dipakai adalah pantovle dengan ujungnya mengecil. Busana perempuan tahun 70-an identik dengan pakaian terusan, dengan ikat pinggang yang besar, sepatunya secara umum berhak tinggi, dengan hak yang lebar dan besar. Model rambut, sebagian ada yang dikucir buntut kuda, ada pula yang digerai kesamping. Biasanya ada hiasan bunga yang dipasangkan pada rambut.

\section{Tata Rias}

Tata rias merujuk kepada perwujudan rias wajah dan tata rambut. Tata rias yang digunakan di dalam pementasan Kemuning adalah tata rias realis. Tata rias realis adalah tata rias yang masih menunjukkan karakter wajah aslinya. Teknik merias hanya menebalkan atau mempertegas garis-garis wajah sehingga ekspresi wajah dapat terlihat oleh penonton. Tata rias untuk Pelacur terkesan menor diwujudkan sedekat mungkin dengan aslinya.

\section{Koreografi (Tari)}

Koreografi pada pementasan Kemuning menggunakan referensi gerakan yang didasari dari gerakan dengan idiom tari Jawa dan gerakan yang sifatnya sensual dan erotis. Gerakan dengan idiom Jawa diaplikasikan pada lagu Kembang sore yang merupakan aransemen lagu Walang Kekek karya Waljinah yang diganti syairnya. Gerakan sensual dan erotis diaplikasikan pada adegan-adegan yang berhubungan dengan pelacur, misalnya adegan perkenalan pelacur. Setiap pelacur melakukan gerakan-gerakan sensual dan erotis supaya para pelanggan tertarik pada mereka, gerakan ini dilakukan untuk menawarkan/menjajakan diri para pelacur kepada para pelanggan. Gerakan sensual dan erotis juga diaplikasikan pada koreografi kelompok para pelacur yang menyanyikan lagu Demi Keindahan Dunia yang isinya menceritakan kehidupan dan nasib pelacur.

\section{Musik dan Bunyi}

Musik realis yang dimunculkan di dalam pertunjukan Kemuningini sesuai dengan fungsinya mendukung peristiwa sama seperti kenyataannya. Musik di dalam pementasan Kemuning mengandung unsur ilustrasi yaitu membawa suasana, seperti suasana gembira, sedih, tegang, dan marah. Selain itu musik juga menunjukkan set waktu, seperti waktu pagi hari, siang hari, atau malam hari. Perwujudan musik dilakukan secara live, dengan peralatan musik pentatonis dan diatonis. Alat musik gamelan lebih mendominasi, karena tempat kejadian berada di Jawa. Lagu Walang Kekek sengaja dipilih untuk dibawakan, selain lagu tersebut juga beredar pada tahun 1970an, lagu Walang Kekek juga menceritakan tentang bagaimana kita mesti menghargai wanita. Hal ini relevan dengan pandangan tentang feminisme radikal. Lagu Walang Kekek kemudian diganti syairnya sesuai dengan tema, dan di aransemen ulang oleh tim musik.

\section{Penutup}

Dongeng Ande-Ande Lumut menjadi ide dasar dalam penciptaan karya seni ini. Dongeng tersebut ini diadaptasi dan dikemas dalam cerita yang mengambil sudut pandang dari kehidupan para pelacur. Tema sosial menjadi ciri dalam karya-karya teater epik Brecht, khususnya tema yang mengangkat nasib orang kecil yang harus menderita karena kebijakan penguasa, biasanya kisahnya seputar persoalan buruh dan majikan. Kehadiran Kemuning di rumah bordil Kembang Sore menjadi ancaman bagi para pelacur lainnya yang telah ada lebih dulu di Kembang Sore. Secara penampilan tidak dipungkiri Kemuning memang lebih menarik dari pelacur-pelacur lainnya.

Para Pelacur berunding dan membuat kesepakatan, mereka bersedia menerima Kemuning untuk tinggal di rumah bordil Kembang Sore dengan syarat, Kemuning harus mau menuruti permintaan-permintaan dari para pelacur. Kemuning bersedia, meskipun syarat itu adalah melakukan pekerjaan-pekerjaan yang bisanya dilakukan oleh para pelacur, seperti menyapu, mencuci, memijit, bahkan sering pula Kemuning mendapatan perlakuan yang tidak mengenakkan dari para pelacur. Sebenarnya ini semua dilakukan supaya Kemuning kecapekan dan tidak sanggup bekerja lagi, hingga akhirnya, tujuan mereka 
membuat Kemuning tidak betah. Hal inilah yang kemudian membuat para pelacur membuat kelompok baru.

Kelompok baru tersebut adalah kelompok yang diwakili Kemuning, yaitu kelompok untuk orang asing yang dipekerjakan. Dengan kata lain kelompok orang asing itu sebenarnya adalah kelompok buruh bagi para pelacur yang sebelumnya ditampilkan tanpa kelompok. Kelompok berikutnya adalah kelompok majikan yang diwakili para pelacur. Mereka terus mengeksploitasi ketidak berdayaan Kemuning. $\mathrm{Hal}$ inilah yang membuat Kemuning tersiksa luar biasa. Para pelacur (masyarakat) jadi bergerak mengikuti pola nafsu belaka. Di balik itu semua Kemuning berusaha berjuang (bertahan) dari eksploitasi yang dilakukan terhadap dirinya. Hal ini ia lakukan untuk menunggu kedatangan Raden Panji suaminya yang sedang mengembara mencari dirinya. Inilah bentuk kesetiaan Kemuning pada suaminya. Ia rela berkorban melakukan apapun untuk menunggu suaminya, meski itu berat baginya, termasuk memilih menjadi pelacur dalam penyamarannya. Ada kesetiaan yang ingin disampaikan Kemuning lewat perjuangannya.

Melacurkan diri merupakan sebuah kesetiaan, hal ini memang sangat kontradiktif, mana mungkin menjual diri (melacur) justru dikatakan setia, mungkin hanya segelintir orang saja yang masih mau menerima. Begitulah yang dipilih Kemuning dalam pementasan Kemuning ini. Ukuran (sudut pandang) yang dipakai untuk menilai disini bukanlah moral. Apabila moral menjadi tolak ukur, maka pandangan masyarakat terhadap pelacur akan tetap buruk. Stigma masyarakat terhadap pelacur telah terbingkai. Ukuran (sudut pandang) yang dipakai untuk melihat pelacur pada pementasan adalah pekerjaan. Pelacur adalah pekerjaan. Melacurkan diri berarti sedang bekerja. Para penonton, diberi sebuah tawaran baru tentang sudut pandang pelacur. Bisnis pelacuran terbukti masih begitu marak di Indonesia dan terus berkembang. Di setiap kota-kota besar pasti terdapat tempat pelacuran. Di Yogyakarta saja terdapat lebih dari satu tempat, Pasar Kembang, Pantai Parangkusumo, Pantai Samas, belum lagi salon "plus-plus" yang menawarkan "ayam kampus" (mahasiswa/ pelajar yang berprofesi ganda sebagai pelacur). Tempat-tempat pelacuran tersebut begitu mudahnya dapat ditemui dan diakses oleh masyarakat. Hal ini mengindikasikan bahwa sebenarnya negara, dalam hal ini pemerintah melakukan pembiaran terhadap tempat pelacuran tersebut, dan terkesan dikondisikan untuk tetap ada. Bisa jadi pemerintah juga punya ketakutan jika menutup tempat-tempat pelacuran tersebut, mengingat dampaknya sangat signifikan untuk masyarakat. Padahal di sisi lain, pelacuran ini juga menyumbang pendapatan daerah yang cukup besar.

Pada buku Sex For Sale, Potret faktual Prostitusi 27 kota di Indonesia, Yuyung Abdi (2007: 39) mengatakan, di Doly Surabaya, total terdapat lima puluh enam wisma. Perputaran uang satu hari di Doly bisa mencapai sepuluh juta tiap wisma. Di Doly masing-masing wisma harus memberikan uang iuran harian sebesar dua puluh lima ribu kepada muspida setempat (RT, RW, Kelurahan, Kecamatan, Polsek, dan Koramil). Artinya dari lima puluh enam wisma yang ada di Doly, muspida bisa mendapat iuran satu juta empat ratus ribu rupiah tiap hari. Dalam setahun muspida dapat meraup iuran harian sebanyak lima ratus empat puluh juta rupiah. Sangat fantastik. Hal ini pula lah yang membuat tempat-tempat pelacuran itu tetap ada hingga sekarang.

Di sisi lain, kehidupan pelacur sendiri selama ini dipandang sebagai sesuatu yang hitam, padahal banyak diantara para pelacur yang melakukan ini karena terpaksa, biasanya karena tuntutan ekonomi. Hal ini begitu kontradiktif. Para pelacur bekerja melacur untuk memenuhi hidup dan mencukupi perekonomian keluarga, bukankah itu bentuk kesetiaan mereka? Namun banyak orang yang masih berpandangan stereotipe pada pelacur, padahal sangat memungkinkan melihat mereka dari kacamata sebagai seorang wanita yang sedang bekerja. Sebagai mata pencaharian (pekerjaan) tentunya para pelacur ingin bekerja semaksimal mungkin, meskipun nota benenya adalah memberi kepuasan kepada para pelanggan. Tapi itu adalah bentuk ketotalan dan keseriusan dalam menjalani pekerjaan yang mereka lakoni.

Permasalahan tentang kesetiaan dan pelacuran sangat menarik untuk diangkat dalam penciptaan karya seni ini. Ini dikarenakan permasalahan tentang kesetiaan dan pelacuran selalu ada dari masa ke masa, apalagi menyikapi keadaan negara akhir- akhir ini yang sedang dilanda berbagai macam krisis (kesetiaan). 
Karya pementasan Kemuning ini pernah dipentaskan sebelumnya dengan judul yang berbeda, yaitu Ande-Ande Lumut dalam format drama anak-anak di desa Kendaga Kecamatan Banjarmangu Banjarnegara Jawa Tengah. Karya tersebut kemudian direproduksi kembali dengan judul Kemuning \#1. Karya pementasan Kemuning telah mengalami dua kali proses reproduksi. Pada akhirnya pementasan Kemuning yang bertemakan kesetiaan ini dan diangkat dari folklor Ande-Ande Lumut diwujudkan sebagai bentuk upaya untuk melihat pelacur dengan sudut pandang yang lain. Pesan moral tersebut disampaikan secara intrinsik melalui dialog, akting tokoh atau simbol-simbol yang ditampilkan dalam pementasan tersebut.

\section{Kepustakaan}

Aarne, Anti dan Stith Thompson. 1964. The Types of the Folktale (a Classification and Bibliography). Helsinki: Soumalainen Tiedeakatemia Academia Scientiarum Fennica.

Abdi, Yuyung. 2007. Sex For Sale Potret Faktual Prostitusi 27 kota di Indonesia. Surabaya: JP BOOKS.

Boal, Agusto. 1974. Theatre Of The Oppressed atau Teater (bagi) yang tertindas. Buenos Aires.

Brandon, James R. 2003. Jejak-jejak Seni Pertunjukan di Asia Tenggara. Bandung: P4ST UPI.

Bunanta, Murti. 1998. Problematika Penulisan Cerita Rakyat untuk anak di Indonesia. Jakarta: Balai Pustaka.

Dananjaja, James. 1986. Folklor Indonesia Ilmu Gosip, Dongeng, dan lain-lain. Jakarta: Grafiti Pers.

Hartnoll, Phyllis. 1995. The Theatre, a Concise History. Singapore: Thames and Hudson.

Hutcheon, Linda. 2006. The Teory Of Adaptation. New York: Routledge.

Kernodle, George. Portia Kernodle. 1978. Invitation to The Theatre. Atlanta: Harcourt Brace .

Kernodle, George. 2008. Invitation To The Theatre atau Menonton Teater. Yogyakrata: UPT Perpustakaan Institut Seni Indonesia.
Krevolin, Richars. 2003. Rahasia Sukses Skenario Film-Film Box Office, 5 Langkah Jitu Mengadaptasi Apapun Menjadi Skenario Jempolan. Bandung: Mizan Media Utama.

Livingston, Don. 1984. Film And The Director. Jakarta: Yayasan Citra.

Luxemburg, Jan Van. 1989. Tentang Sastra. Jakarta: Intermasa.

Luxemburg, Jan Van, Dkk. 1984. Pengantar Ilmu Sastra. Jakarta: PT. Gramedia.

Mitter, Shomit. 2002. Sistem pelatihan lakon Stanislavsky, Brecht Growtoski, Brook. Yogyakarta: Artline.

Nugroho, Philipus. 2011. "Konsep Teater Epik Brechh dalam film Dogville" Laporan Penelitian. Yogyakarta: Lembaga Penelitian Institut Seni Indonesia Yogyakarta.

Ratna, Kutha. 2011. Teori, Metode, dan Teknik Penelitian Sastra. Yogyakarta: Pustaka Pelajar. 2007. Estetika Sastra dan Buday. Yogyakarta: Pustaka Pelajar.

Soemardjo, Jacob. 1986. Ikhtiar Sejarah Teater Barat. Bandung: Penerbit Angkasa. - Jacob, Saini KM. 1986. Apresiasi Kesusatraan. Jakarta: Gramedia.

Soedarsono. 1986. Kesenian, Bahasa Dan Folklor Jawa. Yogyakarta: Departemen Pendidikan dan Kebudayaan.

Soetomo, Greg. 2003. Krisis Seni Krisis Kesadaran. Yogyakarta: Penerbit Kanisius.

Surasdi. 1986. Ande-Ande Lumut. Solo: Tiga Serangkai.

Teuw, A.. 1980. Tergantung pada Kata. Jakarta: Pustaka Jaya. . 1983. Membaca dan Menilai Satra. Jakarta: Gramedia. . 1984. Sastra dan Ilmu sastra. Jakarta: Pustaka Jaya.

Yudiaryani. 2002. Panggung Teater Dunia. Yogyakarta: Pustaka Godosuli.

Yuliady, Koes. 1995. "Pengaruh Gaya Brecht dalam lakon Opera Primadona karya N Riantiarno" Laporan Penelitian. Yogyakarta: Lembaga Penelitian Institut Seni Indonesia Yogyakarta. 